\title{
METHODS OF IDENTIFICATION OF MUSCLE TISSUE IN MEAT PRODUCTS. PREREQUISITES FOR CREATING A MULTI-LEVEL CONTROL SYSTEM
}

Irina M. Chernukha ${ }^{1}$, Natal'ya L. Vostrikova ${ }^{1 \star}$, Daniil V. Khvostov',

Elena A. Zvereva ${ }^{2}$, Nadezhda A. Taranova ${ }^{2}$, Anatoly V. Zherdev ${ }^{2}$

${ }^{1}$ V.M. Gorbatov Federal Research Center for Food Systems of the Russian Academy of Sciences, Moscow, Russia

${ }^{2}$ A.N. Bach Institute of Biochemistry, Federal Research Centre «Fundamentals of Biotechnology» of the Russian Academy of Sciences, Moscow, Russia

Key words: muscle protein, vegetable protein (soy), animal protein, BEFFE, EIA, electrophoresis, histology, identification

\begin{abstract}
Unfair production and products that do not comply with the declared labeling are currently an acute problem in the field of technical regulation, including with regard to food safety and quality. Given the high added value and multicomponent composition, finished meat products are among the most susceptible to adulteration. Despite the best efforts of regulatory agencies to counteract these inconsistencies, the hidden substitution of cheaper or lower-grade meats is still widespread. One of the main tasks facing research laboratories and testing centers today is the detection of falsification of food products, as well as standardization and certification of techniques necessary to solve such problems. The manufacturer, aware of the current control methods, can go to the deception, using vegetable protein, new unregistered feed additives. To determine the complex changes that occur in products, it is necessary to use methodological approaches in which it is possible to reliably determine these changes. The paper presents an overview of the most commonly used methodologies for assessing the component composition of meat products. Quality assessment of meat products includes control of components of finished products. The most difficult task is to determine the proportion of muscle protein in multicomponent meat products that have undergone heat treatment.
\end{abstract}

\section{Introduction}

Since the modern technologies of the production have suffered serious changes, the problem of the multisided study of the food products, in particular the identification, is extremely actual. It is relating to initial raw and secondary materials, including the technologies for the protein products production from plant raw materials, and at the same time the introduction of artificial origin food additives into food raw materials and food products.

Same time the suddenly increased stream of various, not traditional for our market, imported products, and the increase in the production of new products at numerous small Russian enterprises on their own recipe, often allow the manufacturer to reduce the quality, and to the trade to raise the prices.

There have been tasted, in the world practice, various methods of identification of the composition of finished meat products. However, for today there is no universal methodology, which would allow definitely to interpret the results of determining the quantitative content of muscle tissue in finished meat products.

The introduction of animal protein additives (offal, blood and its fractions, caseinates, melange, etc.) and vegetable origin (soy proteins and oilseeds) allows to stabilize the functional and technological properties of raw meat, improves the consistency, appearance and juiciness of finished meat products, while reducing their cost. Excessive application of such additives can cause falsification of products. Therefore during the assessing the quality of meat products, it is necessary to identify its composition in accordance with the declared normative document $[1,2]$.

The main terms and definitions of the meat industry are regulated by GOST R52427-2005 [3]:

- meat product - the mass fraction of meat ingredients in its composition is more than $60 \%$, made with or without the introduction of non-meat ingredients of vegetable and/or animal and/or mineral origin (the mass fraction of meat ingredients in the composition of canned goods for early age children is not less than $40 \%$, in chopped semi-finished products - for baby food - not less than $45 \%$ ).

- meat-containing product - the mass fraction of meat ingredients in it is from 5 to $60 \%$, made using non-meat ingredients of vegetable and/or animal and / or mineral origin (the mass fraction of meat ingredients in the composition of canned food for early age children from 5 to $40 \%$, in chopped semi-finished products for baby food - from 5 to $45 \%$ ).

- meat and vegetable product - with a mass fraction of meat ingredients in the composition from 30 to $60 \%$, obtained using non-meat ingredients of vegetable origin (the mass fraction of meat ingredients in the formulation of canned food for early age children - from 18 to $40 \%$, in chopped semi-finished products for baby food - from 18 to $45 \%$ ).

- vegetable and meat product - with a mass fraction of meat ingredients in the composition from 5 to $30 \%$, made using non-meat ingredients of vegetable origin 
(the mass fraction of meat ingredients in the formulation of canned food for early age children is from 5 to $18 \%$, in chopped semi-finished products for baby food - from 5 to $18 \%$ ).

Quality assessment of meat products includes the control of finished products components. More difficult is to determine the proportion of muscle protein in multicomponent meat products that have undergone heat treatment.

In the world practice are tested different qualitative and quantitative methods for determination of the composition of food products.

The purpose of this review is to systematize these methods and assess the prospects for their application, taking into account the creation of a multilevel control system.

\section{Main part}

\section{Semi-quantitative methods}

Microstructural (histological) analysis provides to get the information about the composition of the product as a whole and differentiate features of tissue and cell structures. It is labor-intensive and requires special equipment [4].

Besides the qualitative assessment of the composition and characteristics of the meat product, this method can be used for calculation of the amount of most components. Indicators can be presented in a verbal form similar as it is provided for in the German Food Legislation («often», «in sufficient quantity», «rarely», etc.), and in a strict mathematical form - in percentages indicating all necessary and sufficient statistical parameters. At the present stage of development of science and with the availability of computer image analysis systems, the widespread use of such studies has become real.

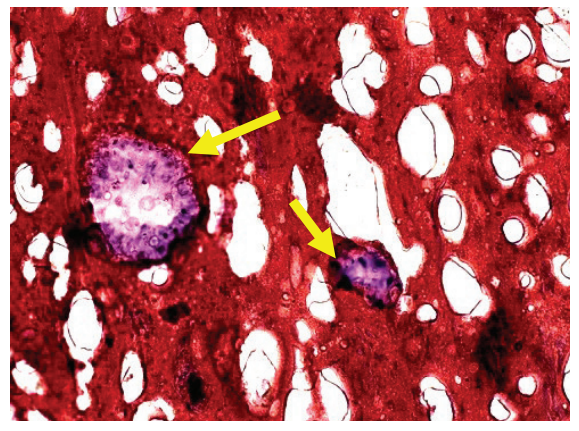

carrageenan

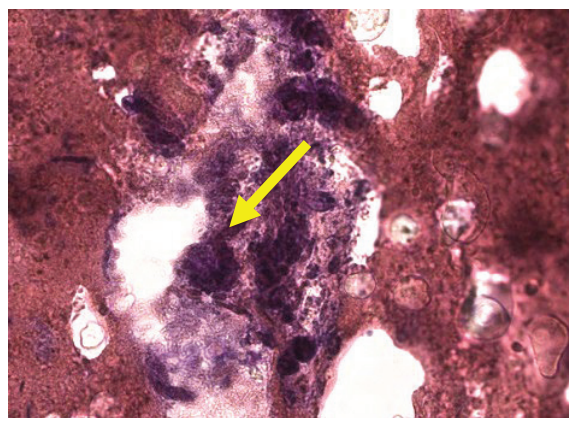

connective tissue fragment
The histological method of assessing the condition and quality of raw meat, as well as the composition of finished meat products is used in many countries mainly in the course of scientific research. The data obtained using the microstructural method of research, serve as a sufficient basis for rejection of the product due to the presence of unacceptable or not provided by the formulation of components, noncompliance of the product with technological regulations [5].

The histological methods give the possibility to assess quickly and objectively the following characteristics of the product: the quality of raw materials used (freshness, cold storage effect, the degree of maturation of meat, etc.), to obtain data on the falsification of raw materials and finished products, to establish the number of unforeseen regulatory documentation additives and determine by what technological form they were used.

For example, the histological examination of Doctor's sausage, developed according to GOST [6], could contain unintended formulation carrageenan, gum, animal protein from pork skins, or a fragment of connective tissue. These inclusions detected in the sausage are shown in Figure 1.

The histological method is used in many countries for identification as composition of meat raw materials as products, mainly in the course of scientific research, and in the practice of testing laboratories, it is included quite rarely, unlike to domestic. The results obtained by histological examination serve as a sufficient basis for classifying the product adulterated, for example, by the presence of ingredients not provided for by the recipe, non-compliance with the prescription composition of the product [4,7]. At the same time, work with biomaterials isolated from food products has a certain specificity, since the matrix is subjected to research after various chemical manipulations.
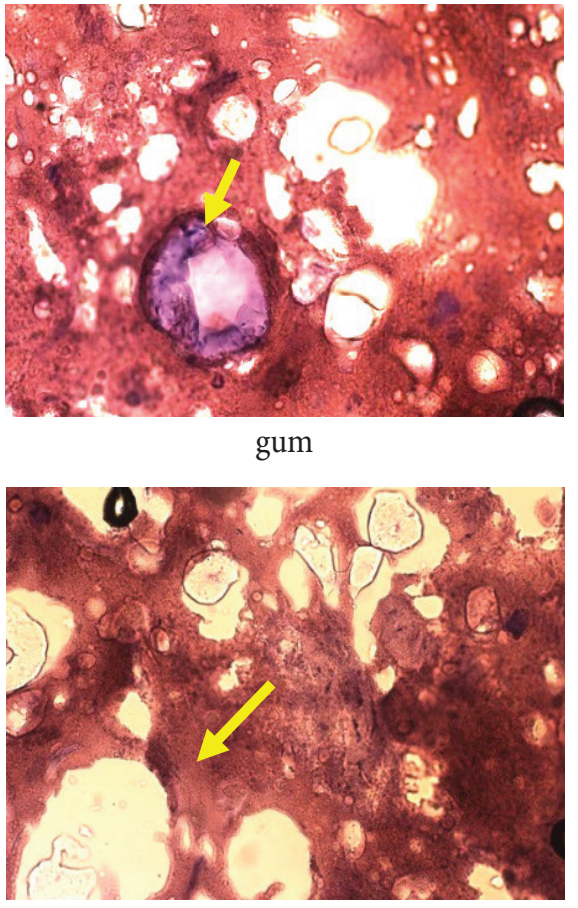

connective tissue

Figure 1. The additives, not provided by GOST, founded in sausage [6] 
The histological method is considered to be labor-intensive due to the use of special equipment and the need for certain practical skills, which causes difficulties in its application in laboratories [7].

The polymerase chain reaction (PCR) method. The DNA-diagnostic methods are used for identification of the species of animal or plant tissues in the meat raw materials and products, including those subjected to heat treatment. PCR is particularly prevalent. Establishing the species of meat using PCR is versatile- and need a specific primer (DNA fragment) for the DNA of a particular animal or plant. This method allows to detect not only species, but also genus, with a high degree of reproducibility and also allows determining $0.01 \%$ of the total volume and is characterized by the possibility of quantitative analysis [8].

The PCR method allows to detect even the single DNA of the desired species, but it can also serve as the limitation of the method: due to accidental contamination of the sample in trace amounts, there is a high probability of issuing a false positive result [9].

The example of identification shown in Figure 2. Currently it is used GOST 31719-2012 «Food and Feed». Express method for determining the raw material composition (molecular)» [10] on the PCR method, which establishes the determination of the species of meat and vegetable ingredients contained in feed, food, food raw materials of plant, animal origin, including those subjected to heat treatment.

Electrophoretic methods: types and application principles. The method of electrophoresis separation of proteins in gel - is widely used in the study of proteins. Electrophoresis consists in the separation of the protein mixture by mass (1DE), and two-dimensional (2DE - two dimensional electrophoresis) - in the sequential use of two properties of proteins: charge and mass, which is necessary for maximum separation of the protein mixture.

The method of electrophoretic determination of the composition of finished products is based on thermal denaturation and extraction of proteins from minced meat, followed by separation of extracted protein fractions in polyacrylamide gel. To obtain more complete picture of the protein composition in the last decade began actively apply the method of two-dimensional electrophoresis. It is established that, closely located bands in the gel can be superimposed. This property prevents the determination of a large number of proteins by one-dimensional electrophoresis. The method of two-dimensional gel electrophoresis in polyacriamide gel (PAAG), combining two different separation procedures, allows the identification of several hundred and sometimes thousands of proteins and peptides. The results are obtained in the form of a protein map in a two-dimensional coordinate system: on the OX axis - the are located the isoelectric point of proteins, on the OY axis - their molecular masses.

The main task of this method is the maximum extraction of proteins from samples that are solubilized with lyzing solutions. Then, dissociated polypeptide chains are separated by isoelectric focusing (IEF) [11]. IEF is the movement of proteins in the $\mathrm{pH}$ gradient under the action of an electric field to the $\mathrm{pH}$ region equal to the isoelectric point (IET) of the protein molecule [12]. The effect of protein IEF has long been known, but attempts to apply it to protein fractionation have long been unsuccessful due to the difficulty of creating a $\mathrm{pH}$ gradient. This problem was solved with the development of synthetic ampholyte-carriers. The ampholites, specially synthesized amphoteric compounds, are polyamine-polycarboxylic acids, which are produced by different companies under different names: ampholines, pharmalites, servalites [13].

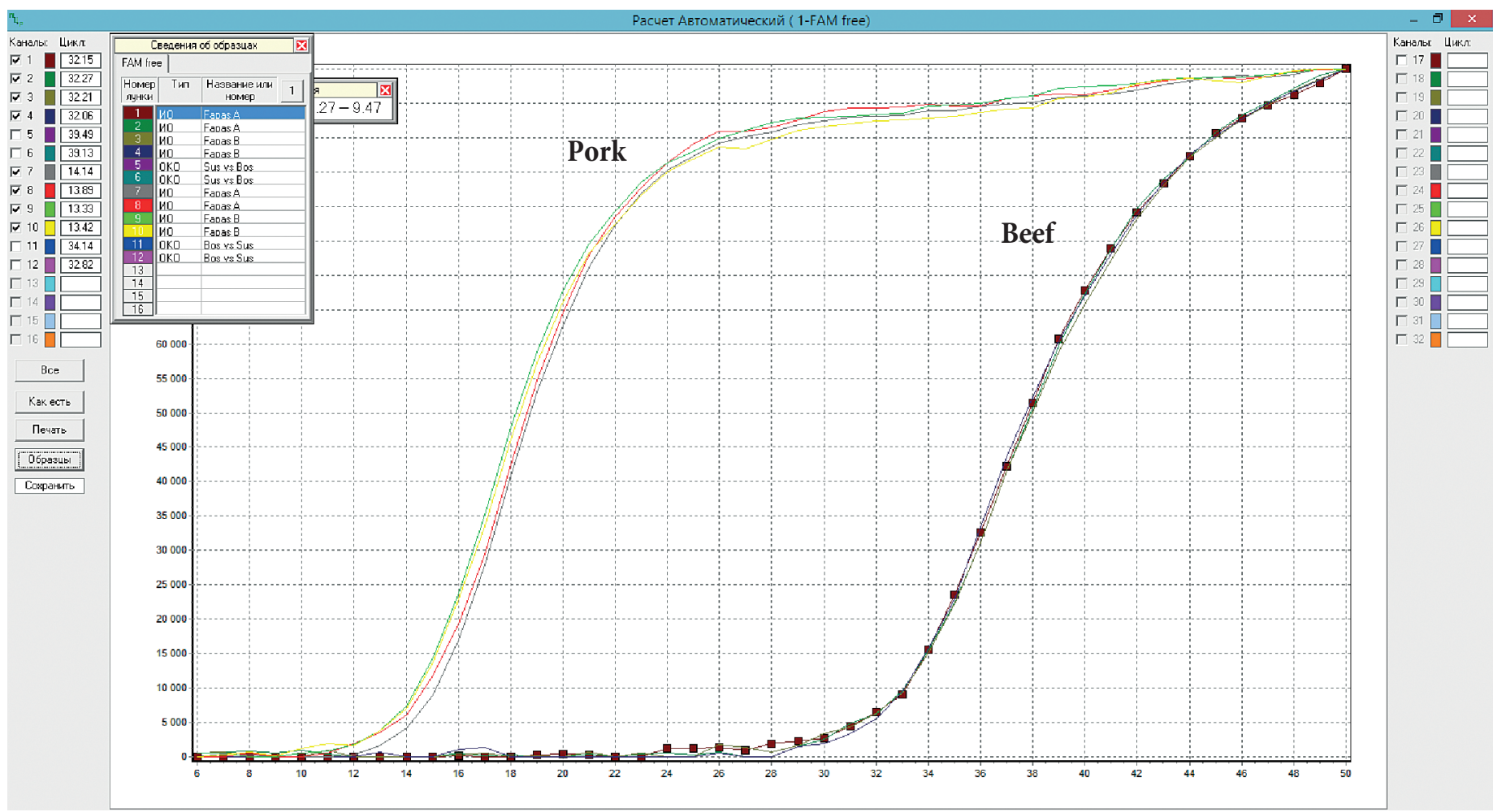

Figure 2. DNA identification of meat by PCR, in boiled sausage 


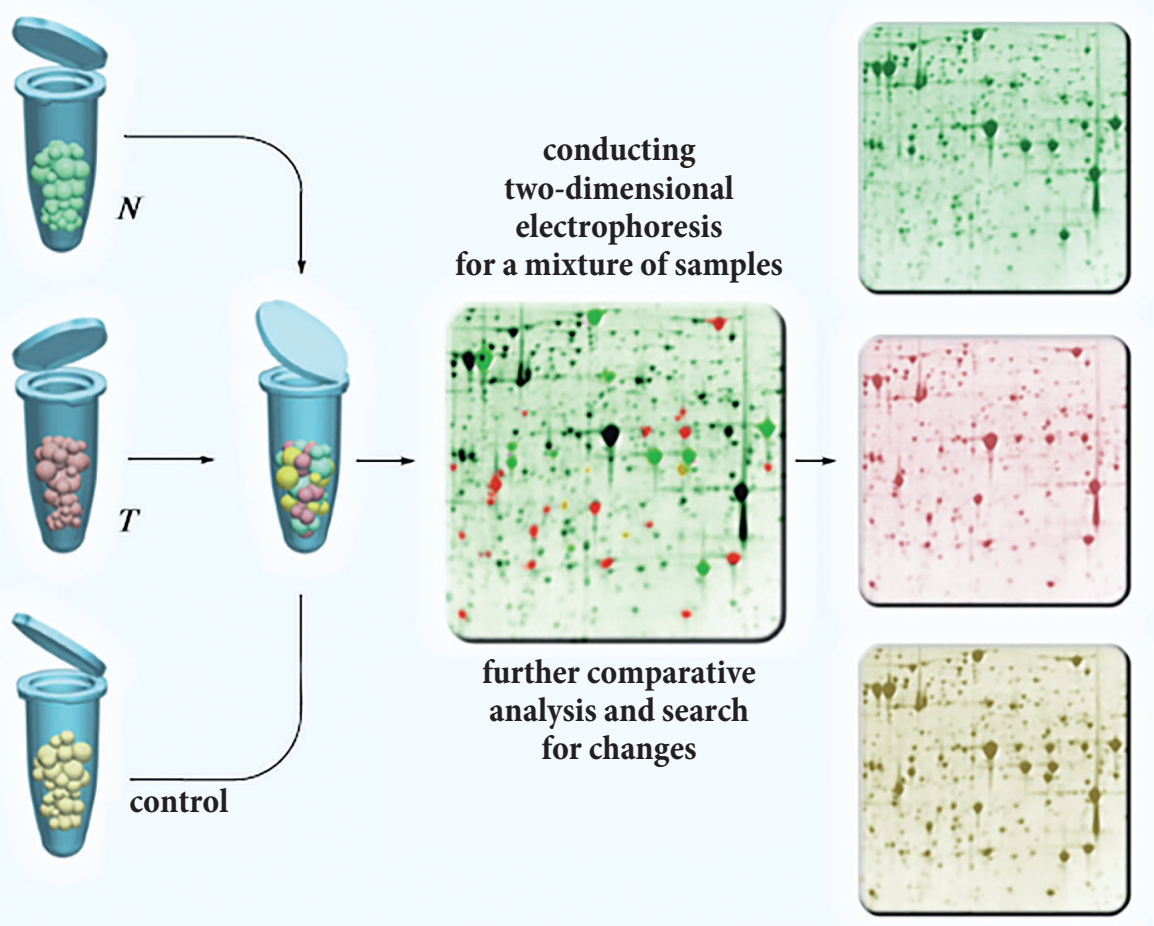

Figure 3. Results of electrophoretic fractionation (2D with cyanine label) of muscle tissue proteins [14]

Thus, in Figure 3 presents 2D electrophoregrams of muscle tissue protein fractionation with cyanine label. Protein extracts of tissue samples are labeled with two different cyanine colorants $(\mathrm{N}, \mathrm{T})$ having different wavelengths of emitted radiation, and mixed. Next, $2 \mathrm{D}$ is carried out, then for each fraction the fluorescence intensity is measured and the difference between the two labels is determined. The method allows to assess their quantitative content by the ratio of the intensity of fluorescence spots also.

There was an improved technology 2D-DIGE - «threedye method», which provides for the use of a special» internal standard», created by combining equal quantities («pooling aliquots») of both test samples [15]. The test samples (experience and control) are labeled with colorants, and the combined internal standard is labeled with a third colorant. Next, the analyzed samples are mixed, and the proteins are fractionated 2D. It is believed that the use of such internal standard allows to reduce the variability of 2D-DIGE gels, facilitates the use of image analysis software (for example, Sangene, DeCyder), with the help of such technique it is possible accurately to determine the amount of protein with a certain statistical certainty [16].

Since the beginning of the postgenomic period, so-called «non-gel» strategies have been developed and actively applied as an alternative to the traditional proteomic strategy [17]. Typically, these strategies include specific sample preparation in which the complex protein mixture is subjected to trypsinolysis or cynogen bromide hydrolysis. The resulting peptide mixture is then fractionated by capillary chromatography in one or more steps in the so-called multidimensional liquid chromatography (MDLC) [18].

The serious disadvantage of $2 \mathrm{D}$ is that the analysis is limited only to a certain subgroup of the cell pro-tein popu- lation [19]. This is partly due to the chemical properties of 2D-based systems, which distinguish mainly between basic and hydrophobic proteins and thus exclude analysis of most receptors and trans-membrane proteins [20]. However, the strongest limitation of $2 \mathrm{D}$ assays is due to the limited dynamic range, which covers only 2-3 orders of amplitude (Pico-nanomolar range), while the ranges of cell protein expression in most tissues cover more than eight orders of amplitude (micro - and femtomolar range). Thus, 2D analysis of non-fractionated tissue samples is limited by the presence of high molecular weight proteins. In this regard, a wide range of methods for preliminary fractionation of complex samples has been developed to solve this problem [21]. Currently, rapidly developing methods of comparative prote-omics and mass spectrometry (MS) identification have to some extent replaced the classical studies based on $2 \mathrm{D}$ electrophoresis.

However, it is considered to be quite time-consuming and costly due to the fact that mass spectrometry MALDI (MS/ MS) is used for quantitative analysis of gels [22].

\section{Calculation methods}

According to the recipe (tab). The aim of the method is to calculate the amount of muscle tissue of the finished product in accordance with the recipe. Standards for manufactured products describe the General definitions and estimates of the feedstock.

The document, that allows to calculate the amount of muscle tissue on the tab of cooked sausages -according to the method described in source [5]. The application of the method implies absolute honesty of the product manufacturer. The high proportion of the falsification cases of the cooked sausages composition (up to $90 \%$ of their volume 
produced according to GOST) leaves no hope for the correct calculation.

$B E F F E$. An indicator that allows to calculate the amount of muscle tissue, for example, in Germany is the BEFFE (bindegewebseiweißfreies Fleischeiweiß - meat proteins, that do not contain connective tissue).

The importance of BEFFE is defined by the German Food Commission in the document «Guidelines for meat and meat products of Germany» as «the difference between total protein and the sum of foreign proteins, foreign nonprotein nitrogen compounds and connective tissue protein». Analyzing the methods and requirements for finished meat products in the EU (on the example of the German experience), the standards describing the General definitions and estimates of raw materials and requirements for designations, beef, pork and poultry meat is divided into three groups or categories. For example, beef with I category per $100 \mathrm{~g}$ in product should contain protein $-18.6 \mathrm{~g}$, fat $-16 \mathrm{~g}$.

The amount of muscle tissue (meat) in the finished product can be determined by calculation based on the results of a complete analysis of the content of chemical components (total protein, fat, moisture, ash, unbound water) in the product. Water, wich content is four times more than amount of protein, is rated as unbound water. Cooked sausages typically contain up to $15 \%$ unbound water.

According to the standards, the value of BEFFE abs should be not less than 7.5\%, and BEFFE real in meat - not less than $75 \%$.

General calculation formula for this indicator:

$$
\text { BEFFE abs }=\% \operatorname{Pr}-\mathrm{Coll} / \mathrm{Pr} \%
$$

BEFFE real $=\left(\right.$ BEFFE $\left.\mathrm{abs}^{\star} 100\right) / \% \mathrm{Pr}$,

where $\% \mathrm{Pr}, \mathrm{Coll} / \mathrm{Pr} \%$ - the amount of total and collagen protein, $\mathrm{g} / 100 \mathrm{~g}$, respectively.

In accordance with the standards of German food legislation, meat products of the highest quality should be differ from ordinary products by a special selection of raw materials [23].

The disadvantage of the method is the need for a long study of the chemical composition of various objects (pork, beef, poultry, etc.) and the preparation of normative documents. There are limitations in this method, consisting in multiple studies of the chemical composition of raw meat and legislative consolidation of certain norms. According to the experience of German colleagues, it is proved, that in order to obtain statistical data, it was necessary to study at least 100 samples of each species, which from an economic point of view is not always advisable.

\section{Quantitative method}

Determination of animal protein by the ratio of amino acids. In Russia there was developed a method for calculating the amount of animal protein by the connective tissue, that is relative to the content of the oxyproline aminoacid [24]. However, it does not allow full identify the composition of the finished wrought products. In German laboratory practice, there is a more accurate method for determining the content of hydrolyzed protein or connective tissue protein (collagen). It is based on sequential extraction with further application of photometric method to identify hydrolysis products (4-dimethylaminobenzaldehyde) and calculation.

In our country, in order to find out the nutritional value of meat, use the ratio of two amino acids: tryptophan and oxyproline. The ratio of tryptophan to oxyproline (4:1) is inversely related to the content of connective tissue.

The proteins of myogen and myosin may be of interest in the aspect of the case in point. It is proved, that muscle sarcoplasm contains myogen, which amounts $20 \ldots 30 \%$ of all muscle tissue proteins, it cannot be attributed to typical globulins, it is easily extracted by the water. The ratio of histi-dine: arginine: lysine in the myogen is 2:4:6.

The composition of myosin is dominated glutamic and aspartic acids, leucine, lysine and arginine. The half of myosin molecule is constructed from all these five aminoacids; the ratio of histidine: arginine: lysine - 2:7:12 [25].

Methods of Mass-spectrometry. The identification of muscle tissue biomarkers. The selection of biomarkers of various components is the promising area of research in the field of determining the composition of finished meat products. Mass spectrometry is an important technique for protein characterization and sequencing. The two main methods of whole protein ionization are electrospray ionization (ESI) and matrix laser desorption/ionization (MALDI). According to the characteristics and mass range of available mass spectrometers, two approaches are used to characterize the proteins. In the first case, intact proteins are ionized by any of the two methods described above, and then injected into the mass analyzer. This approach is called the "top-down" protein analysis strategy. The «top-down» approach, however, is largely limited to lowthroughput studies of a single protein. In the second case, the proteins are enzymatically digested to smaller peptides using proteases such as trypsin or pepsin, either in solution or in gel after electrophoretic separation. Other proteolytic agents are also used. Collected peptide products are often separated by chromatography before being introduced into the mass analyzer.

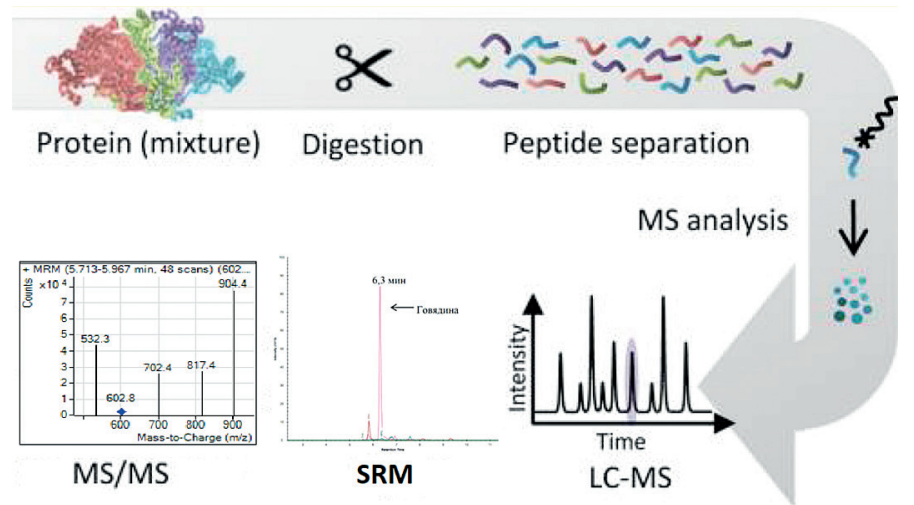

Figure 4. General scheme of preparation and determination of peptide markers [26] 


\section{Immunoanalysis methods}

Immunoanalytic methods are based on highly specific recognition of antibodies of certain structures in antigen molecules. When characterizing the composition of meat products, protein antigens are usually considered, for which the recognizable site (epitope) is from 5-7 to 15-20 aminoacids. The main question during the using of immunoanalysis - is the choice of epitope, peculiar to a strictly defined species. For example, by selecting the antibody, which recognizes a specific protein in the muscles of a pig, we must be sure, that the muscles of a chicken or cow will not detect a protein, that binds to this antibody (just as effectively, or worse, but enough to produce a nonspecific signal). Therefore, immunoanalysis distinguishes well systematically distant from each other organisms or non-muscular additives in meat products, but if necessary, to distinguish closely related species commercially available specific antibodies may be absent, and the development of the analysis will have to start with the search for a unique antigen and antibodies to it.

Despite to these limitations, today there are a number of successful and implemented in practice development of immunomethods for the control of meat products. Almost all of them refer to either microplate enzyme immunoassay (EIA) or immunochromatographic analysis (ICA).

EIA, in the microplate version, includes several stages: preliminary immobilization by antibodies or antigen on the surface of the wells of polystyrene microplate; introduction of a sample containing analyte into the wells; introduction of the enzyme-labeled immunoreagent; preparation of a colored product from the substrate during an enzymatic reaction. The using of the enzyme as a label can significantly increase the analytical signal, since a single enzyme molecule can catalyze the conversion of a large number of substrate molecules into a product. The stages of immunochemical interactions are separated by washing the wells of the microplate with a buffer containing a detergent to remove reagents that have not reacted.

For the determination of low molecular weight compounds, as a rule, a competitive EIA format is used (Figure 5A). High-molecular antigens due to the presence of several disjoint binding sites (antigenic determinants) on surface of them can be detected using not only competitive, but also usually more sensitive «sandwich» format of analysis (Figure 5B). In a situation where the target protein during processing of raw meat can be fragmented and partially denatured (under the action of proteases and temperatures), competitive methods of analysis may be more informative. Effectively working systems realizing both competitive, and «sandwich»-format of EIA are described.

Enzyme immunoanalyses are provided with relatively inexpensive serial equipment that automates the stages of reagent introduction, incubation, washing and final measurements. In poorly equipped laboratories, the analysis can be carried out manually and requires only the use of a vertical photometer for optical measurements in the wells of the microplate. The EIA is a quantitative method that allows to calculate the concentration of antigen in the sample and the proportion of the corresponding raw material in the tested product on the basis of the results obtained.

The EIA is effective for controlling the presence of prohibited types of meat in products, which is of fundamental importance for consumers whose national or religious views do not allow the consumption of certain species of animals meat [32]. It allows to determine both individual types of meat raw materials and the total content of meat raw materials from different sources [33, 34,35,36], as well as to identify additives of non-meat origin in the product [37]. The EIA method for the quantitative determination of soy protein in the composition of various meat, meatcontaining and meat-vegetable food products has been developed in Russia [38].

The microplate EIA allows simultaneous testing up to 40-80 samples. The duration of the analysis is usually from 1.5 to 3 hours. The possibility of the EIA in the kinetic mode with a reduction in duration to $30-40$ minutes is shown, but these approaches are poorly developed methodically and are often accompanied by a decrease in the accuracy of quantitative measurements.

For express monitoring, immunochromatography is of the greatest interest, in which all specific reactions occur on a test strip with deposited immunoreagents. The test strip is a multimembrane composite, in certain areas of which all the necessary immunoreagents and their complexes with a label are previously immobilized (Figure 6). The most frequent used label in ICA is a gold nanoparticles. Upon contact of the test strip with a liquid sample under the action of capillary forces, the movement of the sample components along the membrane occurs, which is accompanied by immunochemical reactions with reagents applied to the membrane. These interactions lead to the formation of colored immune complexes in certain areas of the test strip. Based on the presence or absence of staining of the test line of the test strip, a qualitative conclusion is made about the presence in the sample of a controlled compound - analyte - or about its exceeding the limit concentration (the control line is colored regardless of the composition of the sample and is used to confirm the effectiveness of the reagents.) Quantitative determination of analyte content is carried out according to the intensity of staining, fluorescence or other characteristics of the associated marker, using additional equipment (scanner, video recorder, smartphone camera, etc.). The ICA, like the EIA, can be implemented in competitive and «sandwich» formats.

The advantages of ICA are ease and speed of realization (10-15 min), visual (non-selective) registration of results, and, consequently, possibility of carrying out the analysis on a place of sampling. As a rule, the ICA is inferior to other immunomethods in sensitivity, but in relation to the composition of meat products, this factor is not limiting, and if necessary, additional reagents can be included in the composition of the test-strip, providing signal amplification 


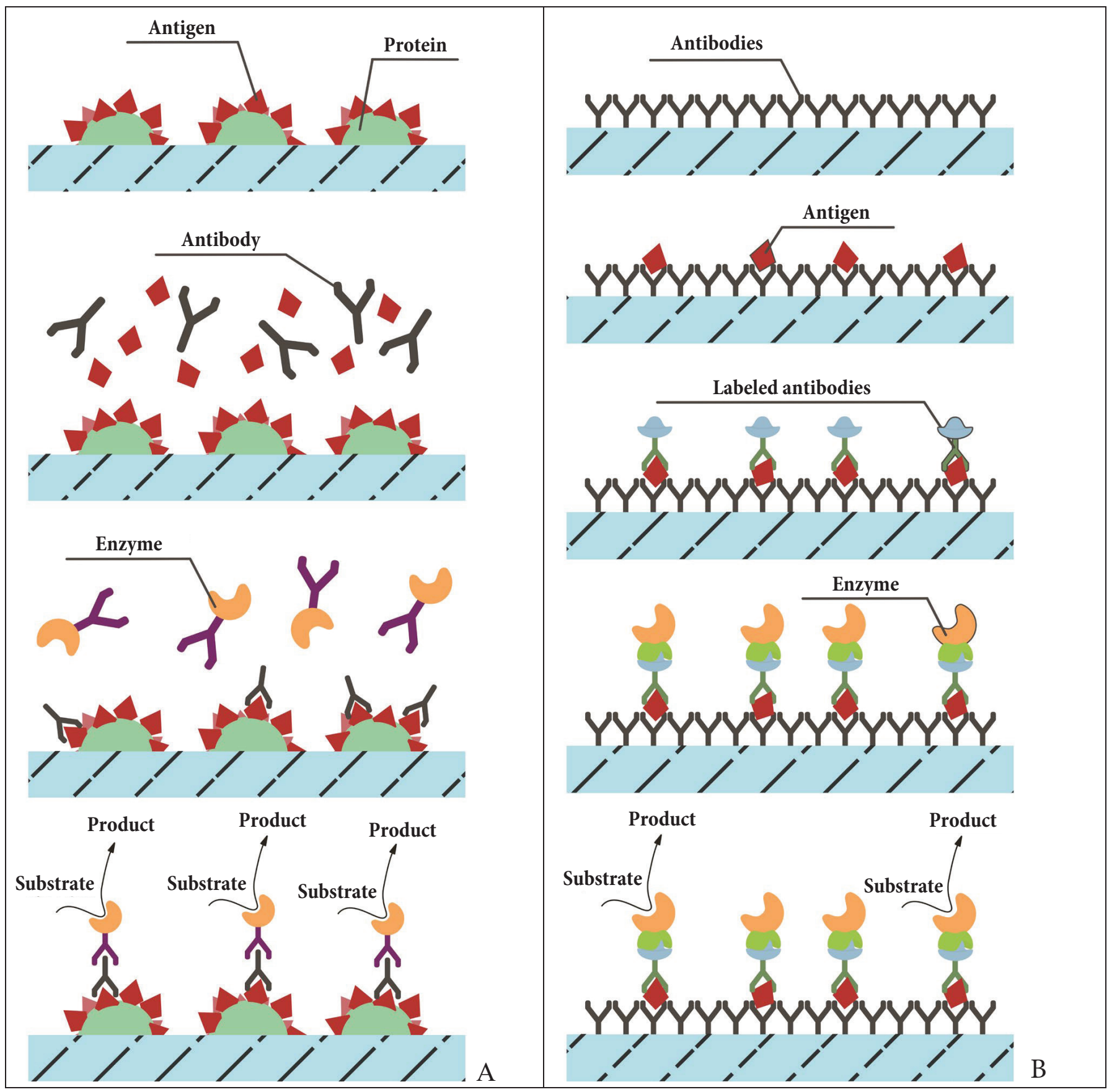

Figure 5. Scheme competitive format (A) and «sandwich»-format (B) of EIA

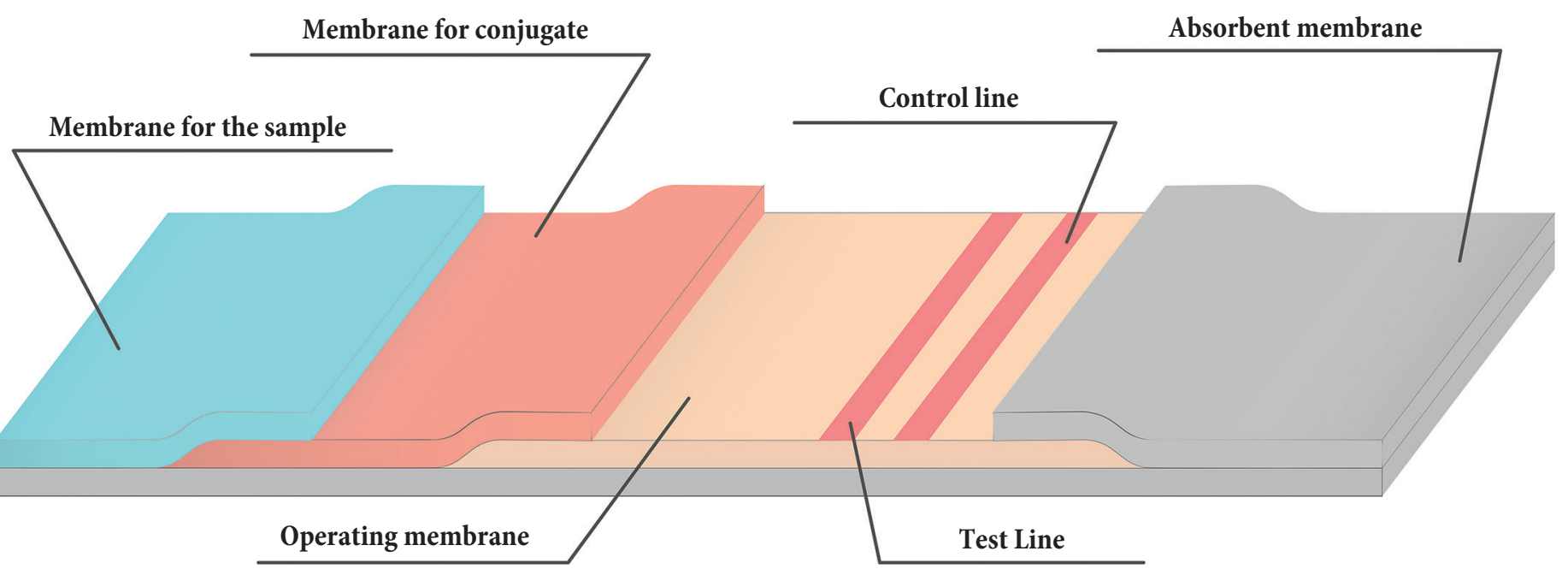

Figure 6. Scheme of immunochromatographic test-strips 
and sensitivity increase by one to three orders of magnitude with preservation of expression and methodological simplicity of testing. Despite the existence of a number of developments on quantitative assessment of analyte content using the ICA, the dominant practice for today, is the use of it for quality control: detection of prohibited components in manufactured products $[39,40]$.

\section{Conclusion}

In the world practice, various methods of identification of the composition of raw materials and ready meat products have been tested. However, at present time, there is no universal methodology that would allow to interpret unambiguously the results of determining the quantity of muscle tissue in finished meat products and the use of undeclared components used in meat production.

Existing standardized methodologies do not allow to decompose fully the composition of the food product into its constituent components. The increasing demands of consumers and the emerging needs of food manufacturers encourage the development and implementation of effective control methodologies, in which a special place is given to the control of the composition of food.

In this regard, we found it relevant to form a set of methods of screening and arbitration control of meat products in order to create a multi-level control system aimed at identifying violations of established formulations.

Applied proteomics and immunodetection aimed at finding the biomarkers of the composition of objects of plant and animal origin and identification signs of authenticity of products will allow quickly and with a high level of reliability to detect cases of falsification.

\section{Acknowledgment}

The work was supported by the Russian Science Foundation (grant 19-16-00108).

\section{REFERENCES}

1. Galkin, A.V., Trepalina, E. (2018). The determination of species of meat raw materials and species composition of finished products by PCR. Myasnoi ryad, 1(71), 36. (In Russian)

2. Khvylya, S.I., Pchelkina, V.A. (2014). The falsifying additives in boiled sausages. Production Quality Control, 2, 43-48. (In Russian)

3. GOST R52427-2005 "Meat industry. Food products. Terms and definitions". Moscow: Standartinform. 2006. - 32 p. (In Russian)

4. Timoshenko, N.V., Patieva, A.M., Patieva, S.V. (2015). The guidelines for laboratory and practical work "Identification of the qualitative composition of meat products. Krasnodar: KubGAU. - 32 p. (In Russian)

5. Chernukha, I.M., Usanova, O. Ye. (2010). Methods for identifying muscle tissues in meat products. Vestnik of the Russian agricultural sciences, 6, 80-82. (In Russian)

6. GOST 33673-2015 "Cooked sausages. General specifications". Moscow: Standartinform. 2016. - 12 p. (In Russian)

7. Pchelkina, V.A., Khvylya, S.I. (2015). The histological analysis - is a method of quality control and composition of meat products. International scientific and practical conference. All-Russian Scientific Research Institute of tobacco, shag and tobacco products, 400-404. (In Russian)

8. Komarova, I.N. (2005). Development of PCR-test systems for species identification and quantitative evaluation of raw meat as a part of finely ground semi-finished and finished meat products. Author's abstract of the dissertation for the scientific degree of Candidate of Veterinary Sciences. Moscow: MGUPB. - 24 p. (In Russian)

9. Popova, S.V. (2012). Application of native and genetically engineered antigens as bioligands in hydrosol preparations for thr express immuno diagnostics. Author's abstract of the dissertation for the scientific degree of Candidate of Bilogical Sciences. Moscow: Moscow State Academy of Veterinary Medicine and Biotechnology named after K. I. Skryabin. - 24 p. (In Russian)

10. GOST 31719-2012 "Foodstuffs and feed. Rapid method of identification of raw composition (molecular)". Moscow: Standartinform. 2014. - 20 p. (In Russian)

11. Skokoreva, A.M., Manzhurina, O.A., Zhmurov, N.G. (2010). Methods of cultivation of microorganisms for industrial purposes. Guidelines of the CPV: "Microbiotechnology". Voronezh. - $56 \mathrm{p}$. (In Russian)

12. Astapova, M.S. (2009). A comparative estimation of the methods on identifying the raw materall of animal and plant origin. Problems on Veterinary Sanitation, Hygiene and Ecology, 1, 90-99. (In Russian)

13. Gorozhanina, E.S. (2007). Method development for identification of raw materials and products of animal and vegetable origin based on SDS-electrophoresis. Author's abstract of the dissertation for the scientific degree of Candidate of Bilogical Sciences. Moscow: VNIIVSGE. - 24 p. (In Russian)
14. Bukurova, Y.A., Krasnov, G.S., Nikitina, I.G., Karpov, V.L., Lisitsyn, N.A., Beresten, S.F. (2013). Methods of searching for markers for serological serum diagnosis of tumors. Molecular biology, 47(1), 1-11. DOI: 10.7868/S0026898413010035.

15. Monteoliva, L., Albar, J.P. (2014). Differential proteomics: an overview of gel and non-gel based approaches. Briefings in functional genomics and proteomics, 3(3), 220-239. DOI: 10.1093/ bfgp/3.3.220

16. Shishkin, S.S., Kovalev, L.I., Kovaleva, M.A., Ivanov, A.V., Eremina, L.S., Sadykhov, E.G. (2014). The application of proteomic technologies for the analysis of muscle proteins of farm animals used in the meat industry (Review). Applied Biochemistry and Microbiology, 50(5), 421-432. Dol: 10.1134/ S0003683814050093

17. Kovaleva, M.A. (2013). Proteomic databases for searching of tissue-specific protein markers of muscular organs. Author's abstract of the dissertation for the scientific degree of Candidate of Technical Sciences. Moscow: The Federal Research Centre "Fundamentals of Biotechnology" of the Russian Academy of Sciences. -42 p. (In Russian)

18. Gao, M., Deng, C., Yu, W., Zhang, Y, Yang, P., Zhang, X. (2008). Large scale depletion of the high-abundance proteins and analysis of middle - and low-abundance proteins in human liver proteome by multidimensional liquid chromatography. Proteomics, 8(5), 939-947. DOI: 10.1002/pmic.200600099

19. Pedersen, M., Bruunsgaard, H., Weis, N., Hendel, H.W., Andreassen, B.U., Eldrup, E.eDela, F., Pedersen, B.K. (2003). Circulating levels of TNF-alpha and IL-6-relation to truncal fat mass and muscle mass in healthy elderly individuals and in patients with type-2 diabetes. Mechanisms of Ageing and Development, 124(4), 495-502. DOI: 10.1016/S0047-6374(03)00027-7

20. Santoni, V., Molloy, M., Rabilloud, T. (2000). Membrane proteins and proteomics: Un amour impossible? Electrophoresis, 21(6), 1054-1070. DOI: 10.1002/(SICl)15222683(20000401)21:6<1054:: AID-ELPS1054>3.0.C0;2-8

21. Spandidos, A., Rabbitts, T.H. (2002). Sub-proteome differential display: Single gel comparison by 2D electrophoresis and mass spectrometry. Journal of Molecular Biology, 318(1), 21-31. DOI: 10.1016/S0022-2836(02)00052-9

22. Shishkin, S.S., Kovalyov, L.I., Kovalyova, M.A. (2004). Proteomic studies of human and other vertebrate muscle proteins. Biochemistry (Moscow), 69(11), 1283-1298.

23. Leitsätze für Fleisch und Fleischerzeugnisse [Electronic resource: https://www.bmel.de/SharedDocs/Downloads/Ernaehrung/Lebensmittelbuch/LeitsaetzeFleisch.html Access date 20.07.2019]

24. GOST 23041-2015 "Meat and meat products. Method for determination of oxyproline" Moscow: Standartinform. 2015. -10 p. (In Russian)

25. Lisitsyn, A.B., Ivankin, A.N., Neklyudov, A.D. (2002). Methods of practical biotechnology. M: VNIIMP. - 402 p. (In Russian) 
26. Switzar, L., Giera, M., Niessen, W. (2013). Protein digestion: an overview of the available techniques and recent developments. Journal of Proteome Research, 12(3), 1067-1077. DOI: 10.1021/ pr301201x

27. Bauer, T., Weller, P., Hammes, W. P., Hertel, C. (2003). The effect of processing parameters on DNA degradation in food. European Food Research and Technology, 217(4), 338-343. DOI: 10.1007/s00217-003-0743-y

28. Terry, C. F., Harris, N., Parkes, H. C. (2002). Detection of genetically modified crops and their derivatives: Critical steps in sample preparation and extraction. Journal of AOAC International, 85, 768-774. PubMed: 12083273

29. Sentandreu, M.Á., Sentandreu, E. (2014). Authenticity of meat products: Tools against fraud. Food Research International, 60, 19-29. DOI: 10.1016/j.foodres.2014.03.030

30. Grundy, H.H., Reece, P., Buckley, M., Solazzo, C.M., Dowle, A.A., Ashford, D., Charlton, A.J. Wadsley, M.K., Collins, M.J. (2016). A mass spectrometry method for the determination of the species of origin of gelatine in foods and pharmaceutical products. Food Chemistry, 190, 17601, 276-284. DOI: 10.1016/j. foodchem.2015.05.054

31. Watson, A.D., Gunning, Y., Rigby, N.M., Philo, M., Kemsley, E.K. (2015). Meat authentication via multiple reaction monitoring mass spectrometry of myoglobin peptides. Analytical Chemistry, 87(20), 10315-10322. DOI: 10.1021/acs.analchem.5b02318 32. Asensio, L., González, I., García, T., Martín, R. (2008). Determination of food authenticity by enzyme-linked immunosorbent assay (ELISA). Food Control, 19(1), 1-8. DOI: 10.1016/j.foodcont.2007.02.010

33. Hsieh, Y.H.P. (2005). Meat species identification. In: Handbook of Food Science, Technology, and Engineering, 533-551. CRC Press. ISBN: 978-146650787-6
34. Zvereva, E.A., Kovalev, L.I., Ivanov, A.V., Kovaleva, M.A., Zherdev, A.V., Shishkin, S.S., Lisitsyn, A.B., Chernukha, I.M., Dzantiev, B.B. (2015). Enzyme immunoassay and proteomic characterization of troponin I as a marker of mammalian muscle compounds in raw meat and some meat products. Meat Science, 105, 46-52. DOI: 10.1016/j.meatsci.2015.03.001

35. Rao, Q., Hsieh, Y.H.P. (2008). Competitive enzyme-linked immunosorbent assay for quantitative detection of bovine blood in heat-processed meat and feed. Journal of Food Protection, 71(5), 1000-1006. DOI: 10.4315/0362-028X-71.5.1000

36. Thienes, C.P., Masiri, J., Benoit, L.A., Barrios-Lopez, B., Samuel, S.A., Cox, D.P., Dobritsa, A.P. Nadala, C., Samadpour, M. (2018). Quantitative detection of pork contamination in cooked meat products by ELISA. Journal of AOAC International, 101(3), 810-816. DOI: 10.5740/jaoacint.17-0036

37. Macedo-Silva, A., Shimokomaki, M., Vaz, A.J., Yamamoto, Y.Y., Tenuta-Filho, A. (2001). Textured soy protein quantification in commercial hamburger. Journal of Food Composition and Analysis, 14(5), 469-478. DOI: 10.1006/jfca.2001.1014

38. MUK 4.1.2881-11. (2011). The definition of soy protein isolate in the composition of meat products. Moscow: The Federal Budgetary Health Institution "Federal center of hygiene and epidemiology" of the Federal office for inspectorate in the field of customers and human well-being protection. - $32 p$. (In Russian)

39. Rao, Q., Hsieh, Y.H. (2007). Evaluation of a commercial lateral flow feed test for rapid detection of beef and sheep content in raw and cooked meats. Meat Science, 76(3), 489-494. DOI: 10.1016/j.meatsci.2006.12.011

40. Kuswandi, B., Gani, A.A., Ahmad, M. (2017) Immuno strip test for detection of pork adulteration in cooked meatballs. Food Bioscience, 19, 1-6. DOI: 10.1016/j.fbio.2017.05.001

\section{AUTHOR INFORMATION}

Irina M. Chernukha - doctor of technical sciences, professor, leading research scientist, Experimental clinic - laboratory «Biologically active substances of an animal origin», V.M. Gorbatov Federal Research Center for Food Systems of Russian Academy of Sciences, 109316, Moscow, Talalikhina str., 26. Tel.: +7-495-676-63-21, e-mail: imcher@inbox.ru

Natal'ya L. Vostrikova - candidate of technical sciences, head of laboratory «Scientific and methodical work, biological and analytical research», V.M. Gorbatov Federal Research Center for Food Systems of Russian Academy of Sciences, 109316, Moscow, Talalikhina str., 26, Tel.: +7-495-676-79-81, e-mail: n.vostrikova@fncps.ru

* corresponding author

Daniil V. Khvostov - junior researcher, laboratory «Scientific and methodical work, biological and analytical research», V.M. Gorbatov Federal Research Center for Food Systems of Russian Academy of Sciences, 109316, Moscow, Talalikhina str., 26, Tel. +7-495-676-79-81, e-mail: daniil_hvostov@mail.ru

Elena A. Zvereva - candidate of biological sciences, senior researcher, Immunobiochemistry Laboratory, Federal Research Center «Fundamentals of Biotechnology» of Russian Academy of Sciences

119071, Moscow, Leninsky prospect, 33, Tel.+7-495-954-28-04, e-mail: zverevaea@yandex.ru

Nadezhda A. Taranova - candidate of chemical sciences, researcher, Immunobiochemistry Laboratory, Federal Research Center «Fundamentals of Biotechnology» of Russian Academy of Sciences

119071, Moscow, Leninsky prospect, 33, Tel. +7-495-954-28-04, e-mail: taranovana@gmail.com

Anatoly V. Zherdev — candidate of biological sciences, leading researcher, Immunobiochemistry Laboratory, Federal Research Center «Fundamentals of Biotechnology» of Russian Academy of Sciences

119071, Moscow, Leninsky prospect, 33, Tel. +7-495-954-28-04, e-mail: zherdev@inbi.ras.ru

Authors are equally relevant to the writing of the manuscript, and equally responsible for plagiarism

The authors declare no conflict of interest

Received 10.08.2019 Accepted in revised 18.09.2019 Accepted for publication 25.09.2019 